\title{
A Novel Class of Antitumor Antibiotics Containing a Cyclodiynene Skeleton : Activity and Mechanism of Action
}

\author{
Masataka Konishi and Toshikazu Oki
}

Bristol-Myers Squibb Research Institute, 2-9-3 Shimomeguro, Meguro-ku, Tokyo 153, Japan

(Received March 20, 1991)

Search for the cytotoxic agents in the microbial metabolites began some 30 years ago largely by Japanese researchers and yielded several clinically aseful anticancer drugs including actinomycin D, mitomycin C, neocarzinostatin and bleomycin. Although these agents are being widely used for the cancer chemotherapy, a large majority of solid tumors such as the lung, intestinal, and liver cancers remain unresponsive, and even at first responsive cancers later develop resistance to the anticancer drugs primarily treated. There is, consequently, an even enhanced need to develop novel types of anticancer drugs for future chemotherapy. The fermentation-derived compounds, antitumor antibi- otics, are considered to be unique resources of the novel chemotypes of antitumor agents.

Recently, a new class of antitumor antibiotics possessing the unprecedented bicyclodiynene system has been discovered. The first examples of this class of antibiotics were esperamicins ${ }^{1,2)}$ and calicheamicins $^{3)}$ which were published at the same time in 1987. Subsequently, dynemicins $\mathrm{s}^{4.5}$, a hybrid of an anthraquinone and a 1,5-diyn-3-ene, was isolated from Micromonospora chersina as a violet colored metabolites. Neocarzinostatin chromophore $^{6)}$, previously characterized as the active principle of anticancer peptide antibiotic neocarzinostatin, was also shown to be a member of this group
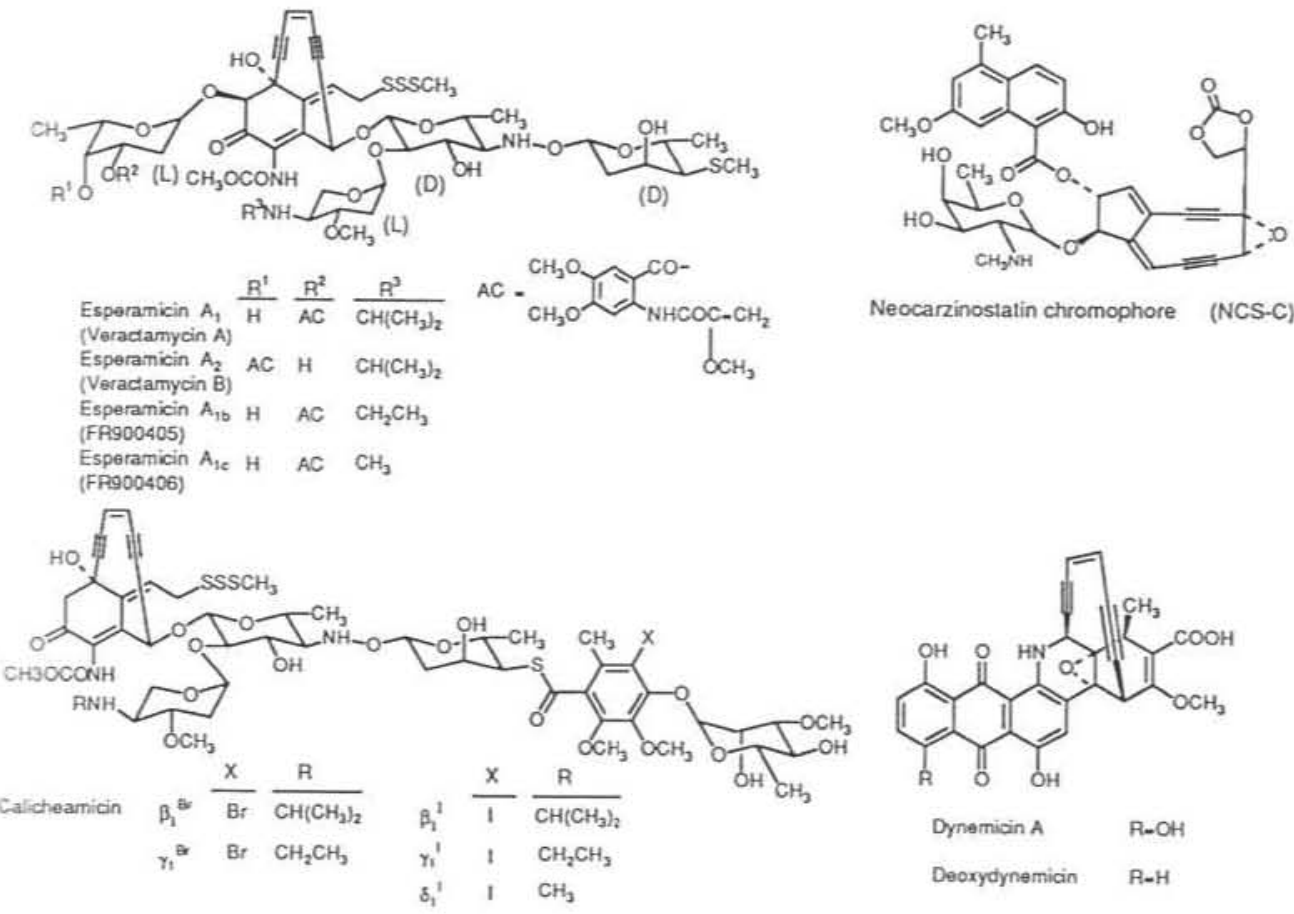

Neocarzinostatin chromophore (NCS-C)

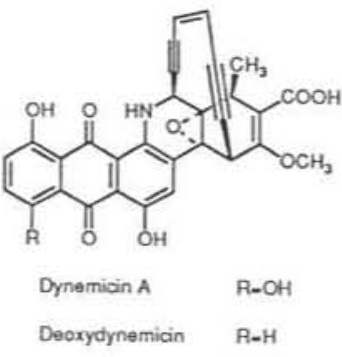

Fig. 1. Chemical structures of the cyclodiynene group of antibiotics 
Table 1. Producing strains of cylodiynene antibiotics

\begin{tabular}{|c|c|}
\hline Antibiotic & Producing organism \\
\hline Esperamicins & Actinomadura verrucosospora H964-92 (ATCC 39332) \\
\hline $\begin{array}{l}\text { Veractamycins } \\
\text { (PD-114759 and -115028) }\end{array}$ & $\begin{array}{l}\text { Actinomadura verrucosospora subsp. veractimyces } \\
\quad \text { (ATCC 39364) }\end{array}$ \\
\hline $\begin{array}{l}\text { FR-900405 and }-900406 \\
\text { (WS-6049) }\end{array}$ & Actinomadura pulvercea sp. nov. No. 6049 \\
\hline Calicheamicins & Micromonospora echinospora sp. calichensis (NRRL 15839) \\
\hline Dynemicins & Micromonospora chersina M956-1 (ATCC 53710) \\
\hline Deoxydynemicin & Micromonospora globosa MG331-HF6 \\
\hline $\begin{array}{l}\text { Neocarzinostatin chromophore } \\
\text { (Neocarzinostatin) }\end{array}$ & Streptomyces carzinostaticus var. F-41 \\
\hline
\end{tabular}

(Fig. 1). The intriguing chemical structures coupled with their extraordinary potency against a variety of bacteria and tumor cells and their unusual mechanism of DNA-cutting action have generated globally the greatest interest of a number of chemists, biochemists and oncologists. This review is summarized the progress of studies on the cyclodiynene antibiotics with emphasis on the activity and mechanism of action.

\section{Discovery, production and chemical structure of the cyclodiynene antibiotics.}

Esperamicins, calicheamicins and dynemicins were discovered in the fermentation broths by using the detection systems highly sensitive to the DNAinteracting compounds. Recombination deficient mutant strains of Bacillus subtilis and Escherichia coli $\left(\operatorname{Rec}^{-}\right)$are known to be more sensitive to the DNA-damaging agents than the wild strains $\left(\operatorname{Rec}^{+}\right)$. The assay system has been used for detection of the chemical mutagens and is called Rec-assay ${ }^{7}$. Esperamicins and dynemicin A were found to exhibit much stronger growth inhibition to the Recmutant of $B$. subtilis than those to the parent strain. The primary in vitro detection system used for calicheamicins was the prophage induction assay $(\mathrm{BIA})^{8)}$. The assay uses a strain of Escherichia coli lysogenic for a $\gamma$-lacZ fusion phage and the induction of $\beta$-galactosidase is detected by colorimetry. Practically, all the cyclodiynene class of antibiotics show extremely potent growth inhibition against bacteria and fungi, particularly against Gram-positive bacteria, and the antimicrobial assay was most conveniently used for detection, isolation and fractionation of the activities. Antitumor potential of these antibiotics were readily detected with their crude extracts as they demonstrated extremely potent in vivo activity against experimental murine tumors such as P388 leukemia and B16 melanoma.

Interestingly, all the three new cyclodiynene antibiotics were isolated from so-called rare actinomycetes, either Actinomadura or Micromonospora strains (Table 1). FR900405 and FR9004069) and veractamycins ${ }^{10)}$ were found as the products of Actinomadura species and later identified to be one of the esperamicin components. Recently deoxydynemicin A was also reported to be produced by Micromonospora species ${ }^{11)}$. Neocarzinostatin was, however, discovered in 1965 as an antitumor antibiotic produced by a Streptomyces strain, the most popular soil actinomycetes. As often observed in the case of potent antibiotics, productivity of the cyclodiynene antibiotics is extremely low. Together with the mutation studies, media improvement and refinement of fermentation conditions were performed for increasing the productivity. A dramatic increase of antibiotic titer was observed when sodium or potassium iodide was supplemented to the fermentation media of esperamicins, calicheamicins and dynemicins. When sodium bromide was added to the media, production of calicheamicins was stimulated. The addition of potassium iodide remarkably promoted an yield of the activities and changed the products from the natural brominecontaining components to new iodine-containing components (Table 2 ) $^{12}$.

The cyclodiynene antibiotics are neutral to 
Table 2. Effects of halide addition on calicheamicin production

\begin{tabular}{lcccc}
\hline & \multicolumn{4}{c}{ Calicheamicin content $(\mu \mathrm{g} / \mathrm{ml})$} \\
\cline { 2 - 5 } Aditition & $\gamma_{1}^{\mathrm{Br}}$ & $\beta_{1}^{\mathrm{Br}}$ & $\gamma_{1}^{\mathrm{I}}$ & $\beta_{1}^{1}$ \\
\hline none & $<0.05$ & 0.1 & $<0.05$ & $<0.05$ \\
$\mathrm{NaBr}(0.05 \%)$ & 2.3 & 0.3 & $<0.05$ & $<0.05$ \\
$\mathrm{KI}(0.01 \%)$ & $<0.05$ & $<0.05$ & 9.8 & 2.6 \\
\hline
\end{tabular}

seakly basic, lipophilic compounds and are unstathe as acid, heat and light. Neocarzinostatin chronoçbore was separated from neocarzinostatin apoprotein fraction by extraction with acidic aqueous methanol solution in a dark room.

The unique structures of the cyclodiynene antitwocos were determined by a combination of careful sepwise degradations and spectroscopic analyses Fig. 1). The heart of the molecules is a bicyclo [7.3.1 or 7.3.0] diynene system which is substituted with a DNA-interacting group (trisaccharide or aromacic nucleus) and a trigger group for activation of the enediyne (allytrisulfide, electrophilic double bond or anthraquinone). In the structural studies of esperamicins, an inactive co-product named esperamicin $\mathrm{X}$ played a vital role. The $\mathrm{X}$-ray analysis semonstrated that esperamicin $\mathrm{X}$ possess a 1,2-disabscinuted benzene in place of the 1,5-diyne-3-ene of the active esperamicin ${ }^{2)}$. A similar aromatized compound, dynemicin $\mathrm{M}$ was also discovered in the fermentation broth of dynemicin ${ }^{4}$ (Fig. 2). These aromarized analogues also served to elucidate the activation mechanism of cyclodiynene antibiotics as discussed in the later section.

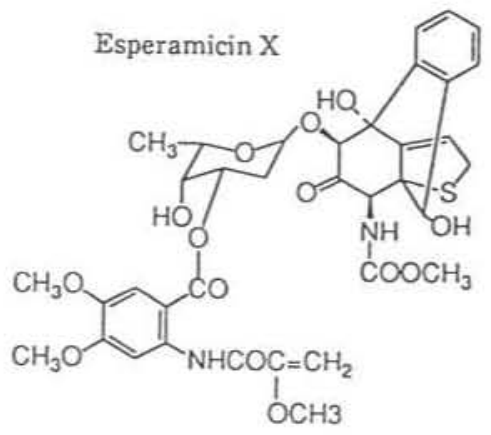

\section{Biological activity of the cyclodiynene antibiotics}

\subsection{Antimicrobial activity}

The cyclodiynene group of antibiotics endows a broad spectrum of antimicrobial activity with extraordinary potency. They are extremely active, $\mathrm{pg} / \mathrm{ml}$ order, against Gram-positive bacteria and highly active, $\mu \mathrm{g} / \mathrm{ml}$ order, against Gram-negative bacteria and fungi. The antimicrobial activity of esperamicins is shown in Table 3-1, and that of four calicheamicin components in Table 3-2 ${ }^{13}$. Esperamicin A2, the positional isomer of the anthranylate of esperamicin A1, is ca. 1/4 - 1/8 as active as esperamicin A1. The antimicrobial activity of calicheamicin $\beta$ and $\gamma$ components are similar to those of esperamicins A1 and A2. The iodine-containing components are slightly more active than the bromine-containing components. The neocarzinostatin chromophore showed only weak antimicrobial activity (MIC: $12.5-50 \mu \mathrm{g} / \mathrm{ml}$ ) probably due to the instability. When the chromophore was re-united with the apo-protein, the antimicrobial activity jumped up ca. 100 fold to the MIC values of 0.1 $3.1 \mu \mathrm{g} / \mathrm{ml}$. The MIC values of dynemicin A and its triacetate are lower (MIC: $0.000006-0.1 \mu \mathrm{g} / \mathrm{ml}$ ) than those of esperamicins and calicheamicins. Interestingly, dynemicin A cured the mice infected with lethal inoculum of Staphylococcus aureus Smith by intramuscular injection $\left(\mathrm{PD}_{50}: 0.13\right.$ $\mathrm{mg} / \mathrm{kg}$ ). The aromatized dynemicin $\mathrm{M}$ exhibited significant in vitro (MIC : $0.2-0.4 \mu \mathrm{g} / \mathrm{ml}$ ) and in vivo activity $\left(\mathrm{PD}_{50} \mathrm{vs} S\right.$. aureus Smith, $1.8 \mathrm{mg} / \mathrm{kg}$, im) against Gram-positive bacteria, which is quite

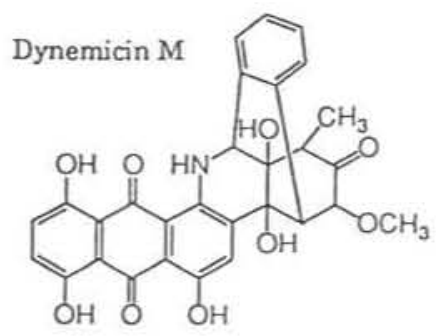

Fig. 2. Naturally-occuring aromatized compounds 
Table 3-1. Antimicrobial activity of esperamicins

\begin{tabular}{lcc}
\hline & \multicolumn{2}{c}{ MIC $(\mu \mathrm{g} / \mathrm{ml})$} \\
\cline { 2 - 3 } \multicolumn{1}{c}{ Organism } & $\mathrm{A}_{1}$ & \multicolumn{1}{c}{$\mathrm{A}_{2}$} \\
\hline Staphylococcus aureus 209P & $<0.0008$ & 0.0063 \\
S. aureus Smith & $<0.0008$ & 0.0031 \\
Bacillus subtilis PCI219 & $<0.0008$ & 0.005 \\
Micrococcus luteus 1001 & 0.0016 & 0.0063 \\
M. flavus & $<0.0008$ & 0.0016 \\
Mycobacterium 607 & 0.05 & 0.1 \\
Escherichia coli NIHJ & 0.1 & 0.8 \\
Klebsiella pneumoniae D11 & 0.4 & 0.8 \\
Pseudomonosa aeruginosa D15 & 0.8 & 1.6 \\
Bacteriodes fragilis A20928 & 0.2 & 1.6 \\
Clostridium difficile A21675 & 0.4 & 0.8 \\
C. perfringens A9635 & 0.05 & 0.8 \\
Candida albicans IAM 4888 & 0.4 & 0.4 \\
Cryptococcus neoformans & 1.6 & 3.1 \\
\hline
\end{tabular}

MIC values were determined by the standard agar dilution method in nuturient agar medium (Gram-positive and Gram-negative bacteria) and Sabouraud dextrose medium (fungi).

contrast to the bio-inactive nature of esperamicin X. This observation implies that the anthraquinone moiety of dynemicin plays an important role in expressing the activity.

\subsection{In vitro cytotoxic activity}

The cyclodiynene antibiotics show exceptional potency, and broad spectrum in vitro and in vivo inhibitory activities against various tumors. On a molar basis, these antibiotics are approximately 1000 - 4000 times more potent than adriamycin and 3 - 10 times more potent than CC- 1065 which had been considered as the most potent antitumor antibiotic $^{14)}$.

When tested by a dye binding assay, esperamicin A1 exerted extremely powerful cytotoxicity to various murine and human cell lines with $\mathrm{IC}_{50}$ values in the $\mathrm{pg}-\mathrm{ng} / \mathrm{ml}$ range $(\text { Table } 4)^{15}$ ). No cross resistance was seen against the vincristine resistant P388 leukemia cells. The same level of unusually strong in vitro cytotoxicity was also reported for veractamycins, FR-900405 and calicheamicins. Esperamicin C, a partial hydrolysis product of esperamicin A1 lacking the anthranyl-2-deoxyfucose moiety, was $1 / 200$ th as potent as esperamicin A1 against HCT-116, Moser and B16 cells in culture. When the methylthiohexose moiety was removed from esperamicin C (esperamicin D), the cytotoxicity dropped to ca. $1 / 1000$ th of esperamicin A1. Further removal of the alkylaminosugar from esperamicin D resulted in nearly complete loss of cytotoxicity and the aromatized esperamicin X became inactive.

Dynemicin A and its tri- $O$-acetate derivative exhibited marked cytotoxic activity comparable to esperamicin A1. Dynemicin M retained significant cytotoxicity against B16 melanoma and Moser

Table 3-2. Antimicrobial activity of calicheamicins

\begin{tabular}{lcccc}
\hline & \multicolumn{4}{c}{ MIC $(\mu \mathrm{g} / \mathrm{ml})$} \\
\cline { 2 - 5 } Organism (strains tested) & \multicolumn{1}{c}{$\beta_{1}^{\mathrm{Br}}$} & $\beta_{1}^{\mathrm{I}}$ & $\gamma_{1}^{\mathrm{Br}}$ & $\gamma_{1}^{1}$ \\
\hline Staphylococcus aureus (7) & $\leq 0.00025$ & $\leq 0.000031$ & $\leq 0.000031$ & $\leq 0.000031$ \\
S. epidermidis (2) & $\leq 0.00025$ & $\leq 0.000031$ & $\leq 0.000031$ & $\leq 0.000031$ \\
Enterococcus sp. (1) & 0.0038 & 0.031 & 0.062 & 0.0078 \\
Bacillus subtilis (1) & $\leq 0.00025$ & $\leq 0.000031$ & $\leq 0.000031$ & $\leq 0.000031$ \\
Escherichia coli (3) & $0.12-0.5$ & $0.25-0.5$ & $0.25-0.5$ & 0.25 \\
Klebsiella pneumoniae (2) & $0.12-0.25$ & 0.5 & 0.5 & 0.25 \\
Enterobacter sp. (2) & $0.25-0.5$ & $0.25-0.5$ & 0.5 & 0.5 \\
Serratia sp. (2) & 0.12 & $0.25-0.5$ & $0.25-0.5$ & $0.12-0.25$ \\
Citrobacter sp. (2) & 0.12 & $0.25-0.5$ & $0.25-0.5$ & $0.12-0.25$ \\
Acinetobacter sp. (2) & $0.06-0.12$ & 0.25 & 0.25 & $0.06-0.12$ \\
Pseudomonas aeruginosa (2) & $0.25-0.5$ & $0.25-0.5$ & $0.5-1$ & $0.12-0.25$ \\
\hline
\end{tabular}

MIC value were determined by the standard agar dilution method in Mueller-Hinton medium. 
Table 4. Cytotoxicity of esperamicins and dynemicins

\begin{tabular}{|c|c|c|c|c|c|c|}
\hline \multirow[b]{2}{*}{ Antibiotic } & \multicolumn{5}{|c|}{$\mathrm{IC}_{50}(\mu \mathrm{g} / \mathrm{ml})$} & \multirow[b]{2}{*}{ K562 } \\
\hline & B16-F10 & Moser & HCT-116 & P388 & P338/VCR & \\
\hline Esperamicin $\mathrm{A}_{1}$ & 0.0018 & 0.000016 & 0.00030 & 0.00005 & 0.00008 & 0.00024 \\
\hline Esperamicin $\mathrm{C}^{1}$ & 0.34 & 0.003 & 0.067 & & & \\
\hline Esperamicin D & 1.84 & $>0.02$ & 0.87 & & & \\
\hline Dynemicin A & 0.0041 & 0.000003 & 0.00028 & 0.00002 & 0.00002 & 0.00008 \\
\hline Triacetyldynemicin A & 0.0027 & 0.000004 & 0.00018 & 0.00002 & 0.00002 & 0.00002 \\
\hline Dynemicin M & 0.12 & 0.40 & & & & \\
\hline
\end{tabular}

colion carcinoma cells, although the activity was mach weaker than dynemicin A.

\section{Antitumor activity}

In as vivo antitumor tests, esperamicin A1 adminisaered intraperitoneally (ip) produced significant proisngation of life span of mice inoculated ip with P38s leukemia, L-1210 leukemia, B16 melanoma, M109 lung carcinoma, C26 colon carcinoma, Y5076 sarcoma or Lewis lung carcinoma at exremely low doses ${ }^{16}$ ). In addition, by intravenous (iv) administration it was effective against iv impuaned P388 (T/C : $125-294 \%$ ) and L1210 (T/C : 175\%) leukemia, as shown in Table 5. Esperamicin A.1 was also active against the MX-1 human manmary tumor xenograft implanted in the subrenal capsule of nude mice, achieving over $85 \%$ intibition of the tumor growth. Calicheamicin $\gamma_{1}^{\mathrm{I}}$ was described to show strong antitumor activity against experimental murine tumors such as P388 leukemia and B16 melanoma at dose of $0.15-10.0 \mu \mathrm{g} / \mathrm{kg}$ with some cured mice at the optimal doses.

Dynemicin A showed in vivo antitumor activity against various experimental tumors at a fairly wide dose range (4-250 $\mu \mathrm{g} / \mathrm{kg})$. The T/C values were, however, relatively low, not exceeding $150 \%$. The weaker antitumor activity and lower $\mathrm{T} / \mathrm{C}$ values of dynemicin A compared to other cyclodiynene antibiotics are presumably due to its pharmaceutical properties such as low water-solubility.

As discussed on the antimicrobial activity, neocarzinostatin chromophore, the active principle of neocarzinostatin is greatly stabilized by noncovalent binding to the apo-protein. Thus, in vivo antitumor activity of the chromophore was much increased in the presence of apo-protein (Minimum effective dose : $5 \mu \mathrm{g} / \mathrm{kg}$, ip).

Table 5. Antitumor activity of esperamicin $A_{1}$

\begin{tabular}{|c|c|c|c|c|c|}
\hline Tumor & (site) & Schedule, & Route & Effective dose $(\mu \mathrm{g} / \mathrm{kg} / \mathrm{inj})$ & Maximum T/C\% (cure/treated) \\
\hline P388 & (ip) & day 1 , & ip & $0.1-30.0$ & $152->300(4 / 6)$ \\
\hline 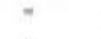 & (ip) & day $1 \rightarrow 9$, & ip & $0.02-3.0$ & 206 \\
\hline " & (iv) & day 1 , & iv & $0.3-10$ & $(3 / 6)$ \\
\hline L1210 & (ip) & day 1 & ip & $1.0-4.0$ & 157 \\
\hline B16 & (ip) & day $1,5,9$, & ip & $0.03-10$ & $210(3 / 10)$ \\
\hline LL & (ip) & day $1 \rightarrow 11$, & iv & $0.1-1.0$ & 286 \\
\hline M109 & (ip) & day $1 \rightarrow 4$, & ip & $0.1-1.0$ & 200 \\
\hline $\mathrm{C} 26$ & (ip) & day $1 \rightarrow 4$, & ip & $0.1-1.0$ & 176 \\
\hline M5076 & (ip) & day $1,5,9,13$ & ip & -1.28 & 156 \\
\hline
\end{tabular}

L1210 (murine leukemia), LL (Lewis lung carcinoma), M109 (Madison 109 lung carcinoma), C26 (colon 26 carcinoma), M5076 (reticulum cell sarcoma). 


\subsection{DNA breakage activity}

The antineoplastic action of the cyclodiynene antibiotics has been shown to be associated with the interaction to and cleavage of DNA by the antibiotics. In the macromolecular synthesis inhibition with esperamicin A1, specific and strong inhibition of DNA synthesis was observed (Table 6). Dynemicin A also inhibits DNA synthesis specifically, with the potency being about $1 / 1000$ th that of esperamicin A1. No specific inhibition of DNA, RNA or protein syntheses was seen for dynemicin $\mathrm{M}$, indicating that the cytotoxic mechanism of dynemicin $\mathrm{M}$ would be different from those of the cyclodiynene antibiotics.

\section{Mechanism of activation of the cyclodiynene antibiotics}

Together with their outstanding biological activity and unprecedent chemical structures, the cyclodiynene antibiotics have elicited the highest attention with their attractive activation mechanism.

The mechanism of action studies to date on these class of agents have identified the following common features for their mode of activation and interaction with DNA. First, they intercalate basespecifically between DNA base pairs using a part of their molecules. They also possess a chemical triggering mechanism which transforms the enediyne core to a high energy intermediate capable of forming biradicals under physiological conditions. The biradical induces either single or double strand DNA scission depending upon the orientation of the core moiety in the minor groove of DNA.

The action mechanism proposed for esperamicins and calicheamicins involves four steps: (1)

Table 6. Inhibition of macromolecular biosynthesis (L1210)

\begin{tabular}{lclc}
\hline \multirow{2}{*}{ Antibiotic } & \multicolumn{3}{c}{$\mathrm{IC}_{50}(\mu \mathrm{g} / \mathrm{ml})$} \\
\cline { 2 - 4 } & \multicolumn{1}{c}{ DNA } & \multicolumn{1}{c}{ RNA } & Protein \\
\hline Esperamicin $\mathrm{A}_{1}$ & 0.0000017 & 0.013 & 0.17 \\
Dynemicin A & 0.0022 & 8.5 & 14 \\
Dynemicin M & $>10$ & 8.2 & $>10$ \\
\hline
\end{tabular}

L1210 cells were incubated with ${ }^{3} \mathrm{H}$-thymidine, ${ }^{14} \mathrm{C}$ uridine or ${ }^{3} \mathrm{H}$-leucine, and the incorporated radioactivities into acid-insoluble fraction were measured by a scintillation counter. thiol compounds such as dithiothreitol and glutathione cleave the allylic methyl trisulfide of the antibiotics, (2) the resulting thiol induces intramolecular Michael type addition to the bridgehead double bond forming a dihydrothiophene, (3) the saturation of the double bond eases the ring strain and decreases the distance between the transannular triple bond terminals, which induces MasamuneBergman type cyclization of the 1,5-diyne-3-ene moiety to form 1,4-dehydrobenzene diradical species, and (4) the diradical abstracts hydrogens from the deoxyribose backbone of nearby DNA (Fig. 3$1)^{12)}$.

In the neocarzinostatin chromophore, thiol compounds are believed to attach to the $\mathrm{C} 12$ position by nucleophilic addition. This generates the double bond shift and epoxide opening producing an ene-yne-cumulene intermediate which in turn cyclizes to a highly reactive indacene biradical ${ }^{177}$. As in the case of esperamicins and calicheamicins, the biradical abstracts hydrogen from the DNA backbone to produce DNA strand breaks (Fig. 3-2).

With combining characteristics of both the enediyne and anthracycline class of antibiotics, dynemicin $\mathrm{A}$ is considered to be activated by a different mechanism. It was evidenced to be greatly activated by NADPH and other reducing agents. These agents appear to reduce the anthraquinone of dynemicin A to the hydroquinone form, which rearranges to the quinonemethide with concomitant opening of the epoxide. Further rearrangement to the quinone form allows approach of the triple bonds and induces cycloaromatization to a dehydrobenzene radical. This causes oxidative DNA strand scission resulting in DNA damage and cell death (Fig. 3-3) ${ }^{18}$ )

Another interesting mechanistic feature is the base-specific DNA single and double strand cleavages observed in the cyclodiynene antibiotics. This is supposed due to a result of a unique binding of the compounds to DNA base pairs. The extensive DNA cleavage studies using a variety of oligonucleotides indicated that the preferred cutting sites are $\mathrm{T}>\mathrm{C} \gg \mathrm{A}>\mathrm{G}$ for esperamicins, $\mathrm{C} \gg \mathrm{T}>\mathrm{A}=\mathrm{G}$ for calicheamicins and $\mathrm{T}>\mathrm{A}>\mathrm{C}>\mathrm{G}$ for neocarzinostatin chromophore. The 3'-sides of purine bases are specifically attacked by dynemicin A. Among them, calicheamicins show the greatest sequence selectivi- 
- Esperamicin -
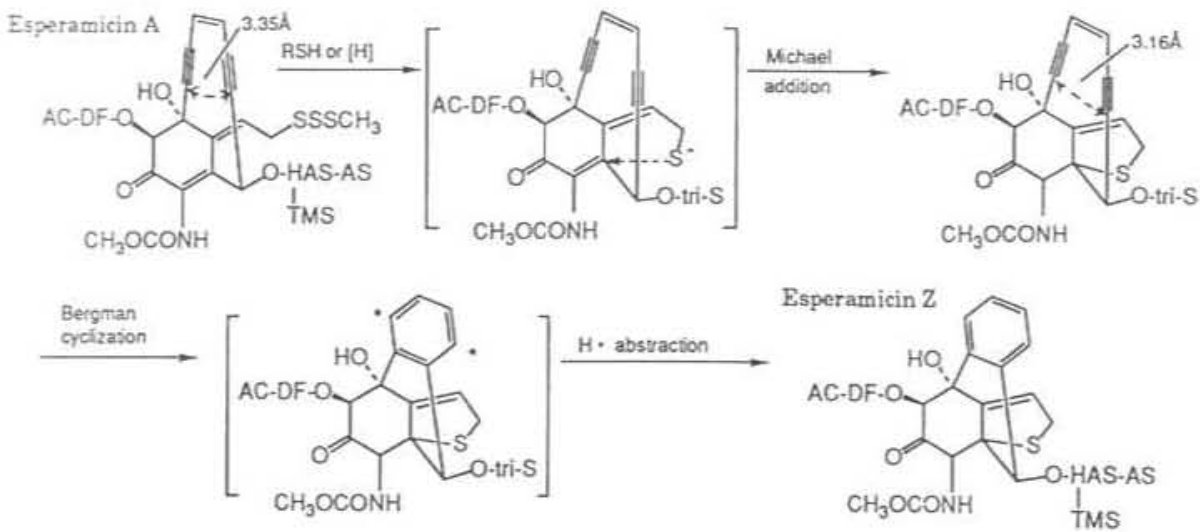

2 - Neocarzinostatin Chromophore -
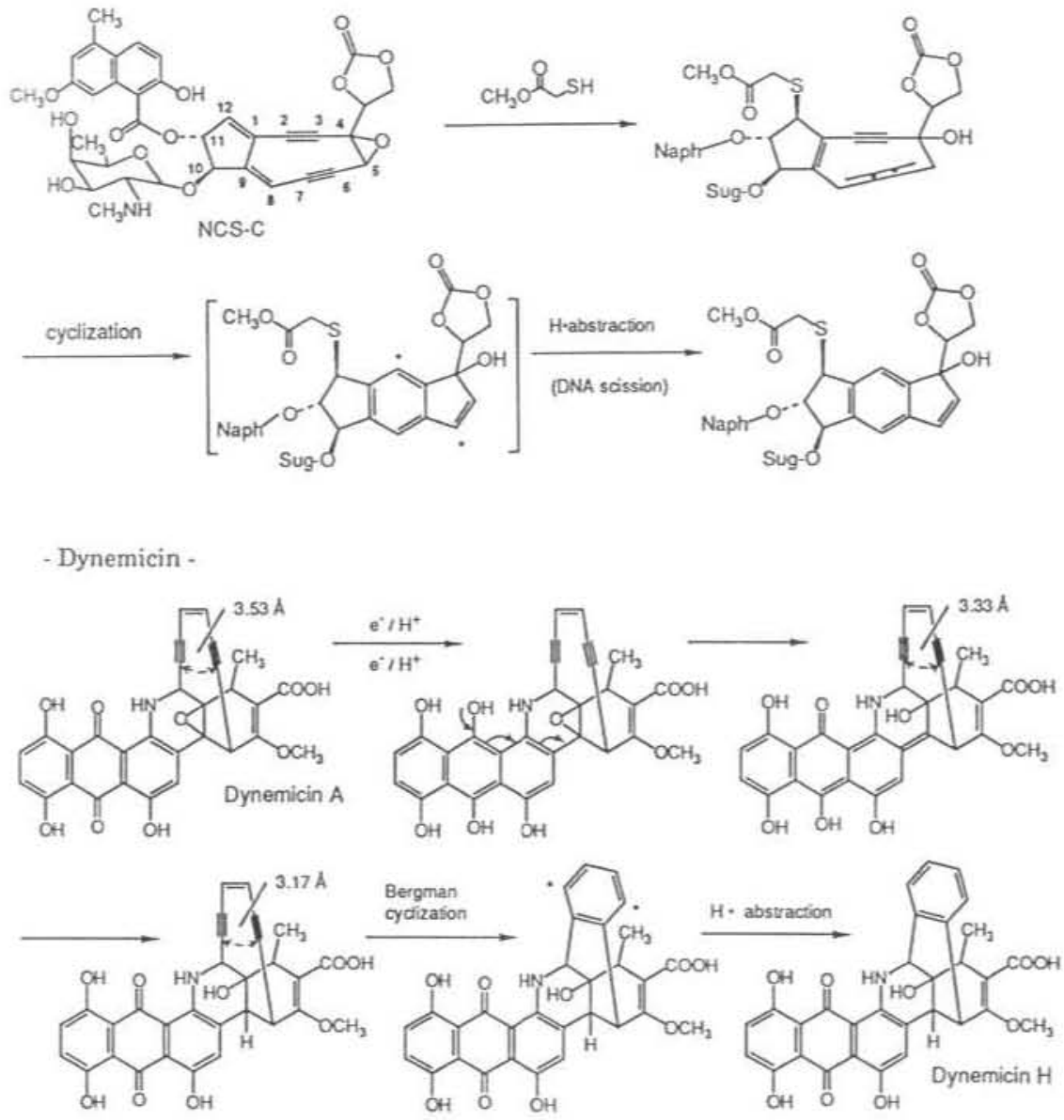

Fig. 3. Proposed mechanism of activation 
ty in its cleavages of double stranded DNA. Recent studies demonstrated that the antibiotics recognize 5'-AGGA/3'-TCÉT pair exclusively and cause strong strand breaks at the underlined cytidine and the 3 base-pair apart base of the opposite strand ${ }^{19)}$. This specificity is considered to be due to the close association of the thiobenzoate-carbohydrate of calicheamicins with the minor groove of DNA. Significant alteration of the cleavage site by pretreatment with a minor groove binder such as netropsin and distamycin substantiated the assumption. Lacking the thiobenzoate-rhamnoside moiety at the trisaccharide terminal, esperamicins are less base-specific than calicheamicins and break both single and double strands. The trisaccharide moiety, however, has been proved to play a key role in the binding of esperamicins to DNA. Neocarzinostatin chromophore breaks single and double strands through binding to double stranded DNA via intercalation of its naphthoate moiety into the minor groove.

The hydroxyanthraquinone of dynemicin $\mathrm{A}$ is believed to serve as a DNA recognition site in addition to as a bio-activation trigger. Dynemicin A causes typical double-strand cuts, and the preferential cutting sites of the antibiotic (3'-side of purine bases such as 5'-AT and 5'-GT) are clearly different from those of other cyclodiynene antibiotics. It also breaks the 3 base-pair apart bases on the 3'-side of complementary strand, which are characteristic of double strand breakage by the minor groove interacting agents. The strong inhibition of the dynemicin-induced DNA cleavage was seen by the pretreatment with distamycin and anthramycin, supporting the minor groove intercalation of dynemicin.

\section{SUMMARY}

The cyclodiynene class of antibiotics esperamicins, calicheamicins and dynemicins represent a new type of antitumor agents possessing highly unusual chemical, biological and mechanistic properties. The extensive studies done so far on these antibiotics gave us a new understanding of how the novel molecules work to kill tumor cells. Neocarzinostatin, without the knowledge of its chemical structure and action mechanism, has been marketed as an anticancer drug since 1977 in Japan and esperamicin A1 is now under clinical trial in Europe and the United States. With their extreme antitumor potency, esperamicins and calicheamicins are considered to become an ideal targeting drug in combination with a monoclonal antibody, and the works toward such directions are in progress.

Inspired by their structural novelty and fascinating mechanism of action, a number of research groups have challenged the total synthetic studies of neocarzinostatin chromophore, esperamicins, calicheamicins and dynemicins. Although considerable progress has already been made, none of these interesting molecules has been totally synthesized so far. However, a great deal of the model compounds having a cyclo-diynene nucleus have been synthesized, and some of them were proved to have DNA-cleaving activity and even cytotoxicity. More interestingly, several appropriately substituted acyclic diynene models are also effective in cleaving DNA. These synthetic works and further mechanistic studies on the cyclodiynene antibiotics are expected to provide us novel antitumor drugs for the future cancer chemotherapy.

\section{REFERENCES}

1)Konishi, M.; H. Ohkuma, K. Saitoh, H. Kawaguchi, J. Golik, G. Dubay, G. Groenewold, B. Krishnan \& T. W. Doyle : Esperamicins, a novel class of potent antitumor antibiotics I. Physico-chemical data and partial structure. J. Antibiot. 38: 1605-1609, 1985.

2)Golik, J.; G. Dubay, G. Groenewold, H. Kawaguchi, M. Konishi, M. Krishnan, H. Ohkuma, K. Saitoh \& T. W. Doyle : Esperamicins, a novel class of potent antitumor antibiotics. 3. Structures of esperamicins A1, A2 and A1b. J. Am. Chem. Soc. 109: 3462-3464, 1987

3)Lee, M.D.; T.S. Dunne, C.C. Chang, G.A. Ellestad, M.M. Siegel, G.O. Morton, W.J. McGahren \& D.B. Borders: Calicheamicins, a novel family of antitumor antibiotics. 2. Chemistry and structure of calicheamicin $\gamma_{1}^{1}$. J. Am. Chem. Soc. 109: 3466-3468, 1987

4)Konishi, M.; H. Ohkuma, K. Matsumoto, T. Tsuno, H. Kamei, T. Miyaki, T. Oki, H. Kawaguchi, G.D. VanDuyne \& J. Clardy: Dynemicin A, a novel antibiotic with the anthraquinone and 1,5-diyne-3-ene subunit. J. Antibiot. 42: $1449-1452,1989$.

5)Konishi, M.; H. Ohkuma, T. Tsuno, T. Oki, G.D. VanDuyne \& J. Clardy: Crystal and molecular structure of dynemicin A : A novel 1,5-diyne-3-ene antitumor antibiotic. J. Am. Chem. Soc. 112:3715-3716, 1990.

6)Edo, K.; Mizugaki, Y. Koide, H. Seto, K. Furihata, N. Ohtake \& N. Ishida: The structure of neocarzinostatin chromophore possessing a novel bicyclo $[7,3,0]$ dodeca- 
Avo swstem. Tetrahedron Lett. 26: 331-334, 1985.

Fida. T; K. Tutikawa \& Y. Sadaie: In vitro and hostmesied "rec-assay" procedures for screening chemical mumgeos: and philoxine, a mutagenic red dye detected. Marnocon Res, 16: 165-174, 1972.

s Elesperu, R.K \& R.J. White: Biochemical prophage inducang assay: A rapid test for antitumor agents that interact with DNA. Cancer Res. 43: 2819-2830, 1983.

q Krovo, S. : M. Nishizawa, H. Terano, M. Kohsaka, H. sake H. Imanaka, Y. Kawai, I. Uchida \& M. Hashimoto: $\mathrm{Cev}$ incitumor antibiotics, FR-900405 and FR-900406 II. 7robacson, isolation, characterization and antitumor activi7. 1 Antibiot. $38: 840-848,1985$.

indumge R.H; T.R. Hurley, T.A. Smitka, N.E. Willmer, A.J. Bnmicesicz, C.E. Steinman \& J.C. French: PD114,759 ant PD115.028, novel antitumor antibiotics with phenemenal potency. I. Isolation and characterization. J. Armibice 37: 1566-1571, 1984.

11 Shicen, K. ; H. Iinuma, H. Naganawa, M. Hamada, S. Fancr. H. Nakamura, T. Takeuchi \& Y. litaka: New antihone produced by Micromonospora globosa. J. Antibiot. fs. $1000-1005,1990$.

ZLe MD.; J.K. Manning, D.R. Williams, N.D. Kuck, R.T. Tes 5 D. B. Borders: Calicheamicins, a novel family of anumar antibiotics. 3. Isolation, purification and characeraocon of calicheamicins $\beta_{1}^{B r}, \gamma_{1}^{B r}, \alpha_{2}^{I}, \alpha_{3}^{1}, \beta_{1}^{1}, \gamma_{1}^{1}$ and $\delta_{1}^{1}$. J. Amitnoc. 42: 1070-1087, 1989.

IMliese, W.M. ; M.P. Lechevalier, H.A. Lechevalier, J. Korstalla, N. Kuck, A. Fantini, M.J. Wildey, J. Thomas \&
M. Greenstein: Calicheamicins, a novel family of antitumor antibiotics: Taxonomy, fermentation and biological properties. J. Antibiot. 42: 558-563, 1989.

14)Hanka, L.J.; A. Dietz, S.A. Gerpheide, S.L. Kuentzel \& D.G. Martin: CC-1065 (NSC-2928223), a new antitumor antibiotic. Production, in vivo biological activity, microbiological assays and taxonomy of the producing microorganism. J. Antibiot. 31: 1211-1217, 1978.

15)Long, B.H.; J. Golik, S. Forenza, B. Ward, R. Rehfuss, J.C. Dabrowiak, J.J. Catino, S.T. Musial, K.W. Brookshire \& T.W. Doyle: Esperamicins, a class of potent antitumor antibiotics: Mechanism of action. Proc. Natl. Acad. Sci. USA 86: 2-6, 1989.

16)Schurig, J.E.; W.C. Rose, H. Kamei, Y. Nishiyama, W.T. Bradner \& D.A. Stringfellow: Experimental antitumor activity of BMY-28175 a new fermentation derived antitumor agent. Investigational New Drugs 8: 7-15, 1990.

17)Myers, A.G.: Proposed structure of the neocarzinostatin chromophore-methyl thioglycolate adduct; A mechanism for the nucleophilic activation of neocarzinostatin. Tetrahedron Lett. 28: 4493-4496, 1987.

18)Sugiura, Y.; T. Shiraki, M. Konishi \& T. Oki; DNA intercalation and cleavage of an antitumor antibiotic dynemicin that contains anthracycline and enediyne cores. Proc. Natl. Acad. Sci. USA. 87: 3831-3835, 1990.

19)Zein, N.; M. Poncin, R. Nilakantn \& G. A. Ellestad: Calicheamicin $\gamma_{1}^{1}$ and DNA: Molecular recognition process responsible for site-specificity. Science 244: 697-699, 1989. 